Article

\title{
Expression, Purification, and Characterization of a Novel Hybrid Peptide with Potent Antibacterial Activity
}

\author{
Xubiao Wei ${ }^{\dagger}$, Rujuan $\mathrm{Wu}^{\dagger}{ }^{\dagger}$, Lulu Zhang, Baseer Ahmad, Dayong Si ${ }^{*}$ and Rijun Zhang * \\ Laboratory of Feed Biotechnology, State Key Laboratory of Animal Nutrition, College of Animal Science and \\ Technology, China Agricultural University, Beijing 100193, China; Weixubiao01@cau.edu.cn (X.W.); \\ Lingxiabenpao@aliyun.com (R.W.); zhanglulu09@cau.edu.cn (L.Z.); dr.baseerahmadkhan@gmail.com (B.A.) \\ * Correspondence: dayong@cau.edu.cn (D.S.); zhangrj621@126.com (R.Z.); Tel.: +86-10-6273-1208 (D.S. \& R.Z.) \\ + These authors contributed equally to this work.
}

Received: 16 April 2018; Accepted: 30 May 2018; Published: 20 June 2018

\begin{abstract}
The hybrid peptide cecropin A (1-8)-LL37 (17-30) (C-L), derived from the sequence of cecropin A (C) and LL-37 (L), showed significantly increased antibacterial activity and minimized hemolytic activity than $\mathrm{C}$ and $\mathrm{L}$ alone. To obtain high-level production of $\mathrm{C}-\mathrm{L}$, the deoxyribonucleic acid sequence encoding $\mathrm{C}-\mathrm{L}$ with preferred codons was cloned into pET-SUMO to construct a fusion expression vector, and overexpressed in Escherichia coli (E. coli) BL21 (DE3). The maximum fusion protein (92\% purity) was obtained with the yield of $89.14 \mathrm{mg} / \mathrm{L}$ fermentation culture after purification with Ni-NTA Sepharose column. The hybrid C-L was cleaved from the fusion protein by SUMO-protease, and $17.54 \mathrm{mg} / \mathrm{L}$ pure active $\mathrm{C}-\mathrm{L}$ was obtained. Furthermore, the purified $\mathrm{C}-\mathrm{L}$ showed identical antibacterial and hemolytic activity to synthesized C-L. Stability analysis results exhibited that the activity of $\mathrm{C}-\mathrm{L}$ changed little below $80^{\circ} \mathrm{C}$ for $20 \mathrm{~min}$, but when the temperature exceeded $80^{\circ} \mathrm{C}$, a significant decrease was observed. Varying the $\mathrm{pH}$ from 5.0 to $10.0 \mathrm{did}$ not appear to influence the activity of $\mathrm{C}-\mathrm{L}$, however, $\mathrm{pH}$ below 4.0 decreased the antibacterial activity of $\mathrm{C}-\mathrm{L}$ rapidly. Under the challenge of several proteases (pepsin, trypsin, and proteinase $\mathrm{K}$ ), the functional activity of C-L was maintained over $50 \%$. In summary, this study not only supplied an effective approach for high-level production of hybrid peptide $\mathrm{C}-\mathrm{L}$, but paved the way for its further exploration in controlling infectious diseases of farm animals or even humans.
\end{abstract}

Keywords: hybrid peptide; fusion expression; Escherichia coli; antibacterial activity; stability

\section{Introduction}

In recent years, more and more efforts have been paid on developing new safe therapeutic compounds to cope with the increasing microbial resistance to conventional antibiotics [1,2]. Antimicrobial peptides (AMPs), a kind of naturally distributed short amphipathic cationic polypeptide, were key players of the defense systems for the majority of living organisms, by killing the invading pathogenic organisms directly and modulating the immune response [3-5]. Studies on both living organisms and simulated membranes have documented that the mechanism of AMPs is completely different from traditional antibiotics. AMPs exerted their antimicrobial activity through several models, including "pore-forming", "barrel-stave", "carpet" model, and so on, and were reported to be less prone to drug resistance than traditional antibiotics [6-8]. Therefore, AMPs show great potential as a pharmaceutical for the treatment of increasing antibiotic-resistant bacterial infections and immunological disease [2-8].

The human cathelicidin peptide, LL37 (L), plays a critical role in the process of antimicrobial infection and wound healing, but also exhibits undesirable hemolytic activity against host cells [9-11]. 
This property greatly limits its application in clinic. Cecropin A (C), isolated from Hyalophora cecropia, is a small linear helical peptide with broad bioactivities. It shows antibacterial, anti-inflammation and anticancer activities, and does not lyse eukaryotic cells [2,12,13]. Hybridizing different AMPs has been an effective method to obtain novel hybrid AMPs with elevated antibacterial activity but minimized cytotoxicity [14,15]. In the previous study from our laboratory, a novel hybrid peptide cecropin A (1-8)-LL37 (17-30) (C-L) was designed by combining the N-terminal amphipathic $\alpha$-helix fragment of $\mathrm{C}$ with the core antimicrobial fragment of L. It possessed significantly greater antibacterial activity against a wide range of pathogens, but displayed minimized (nearly no) cytotoxicity compared to parental peptides ( $\mathrm{C}$ and L) [2]. To obtain large quantities of C-L for physiological and structural investigations, effective production approaches are necessary.

Escherichia coli (E. coli) expression system is effective to produce proteins and peptides, due to its high production, relative simplicity of the DNA manipulation, and low cost [16-19]. By conjoining a partner to the N-terminal of AMPs, a fusion strategy has been employed to eliminate the toxicity of AMPs to host cell and protect AMPs from proteolytic degradation. There are various fusion partners [19-22], among which, SUMO was one of the most effective partners because not only does it facilitate the purification of the fusion protein with His-tag in N-terminal, but it can also be removed by SUMO protease specifically, allowing the recombinant proteins to retain the native $\mathrm{N}$-terminus, which is a critical feature to the antimicrobial activity [20]. In the present research, SUMO-C-L was expressed in E. coli, recombinant C-L was purified, and its antibacterial and hemolytic activity and stability were also assayed.

\section{Results}

\subsection{Construction of Expression Plasmids}

The schematic of construction of the expression vector was depicted in Figure 1. The C-L gene fragment was inserted downstream of SUMO gene to construct recombinant expression plasmids pET-SUMO-C-L. His-tag sequence was at the N-terminus of SUMO. The amino acid sequence of C-L was KWKLFKKIFKRIVQRIKDFLRN. The correct orientation of the insert was confirmed by PCR amplification and DNA sequencing (data not shown).

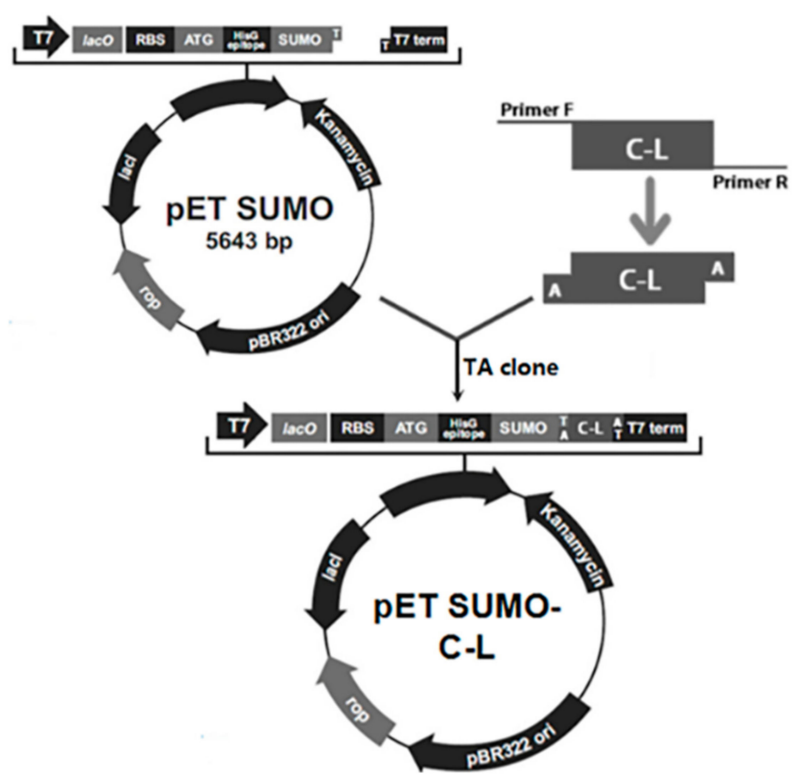

Figure 1. The schematic of construction of expression vector. 


\subsection{Expression of Fusion Protein SUMO-C-L}

The recombinant plasmid pET-SUMO-C-L was transformed into E. coli BL21 (DE3) cells for expression. The gene of hybrid peptide $\mathrm{C}-\mathrm{L}$ was expressed as a fusion protein in recombinant $E$. coli BL21 (DE3) cells with $1.5 \mathrm{mM}$ IPTG induction. After cell disruption and centrifuge, the supernatant was analyzed by $16 \%$ tricine-SDS-PAGE. As shown in Figure 2, an apparent molecular mass of about $18 \mathrm{kDa}$ was detected (calculated molecular mass, $18.1 \mathrm{kDa}$ ). After adding IPTG, the quantity of fusion protein SUMO-C-L increased, and the maximum was observed at $5 \mathrm{~h}$, constituting up to $60.3 \%$ of all soluble proteins in the supernatant determined by Bandscan 5.0 software (Glyko, Novato, CA, USA).

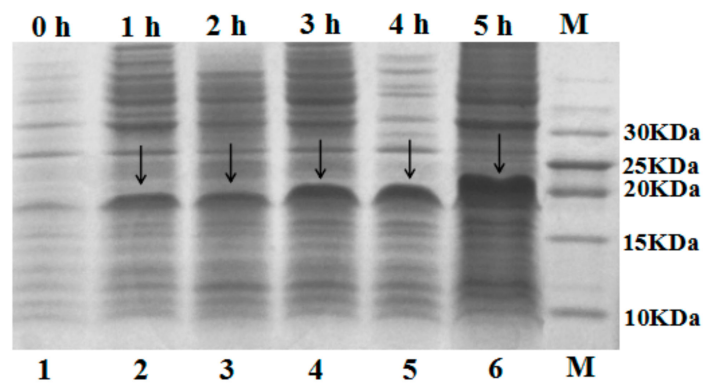

Figure 2. Tricine-SDS-PAGE analysis of supernatant with $1.5 \mathrm{mM}$ IPTG induction. Lane 1, supernatant of non-induced E. coli BL21 (DE3); Lane 2, 3, 4, 5, 6 were supernatant of 1.5 mM IPTG-induced E. coli BL21 (DE3) for 1, 2, 3, 4, $5 \mathrm{~h}$ respectively; Lane $\mathrm{M}$, marker. The arrows indicated fusion protein SUMO-C-L.

\subsection{Purification and Cleavage of Fusion Protein SUMO-C-L}

The soluble fusion protein SUMO-C-L with His-tag enabled the affinity purification through Ni-NTA Sepharose affinity column. Tricine-SDS-PAGE staining with Coomassie blue (Figure 3, lane 3) showed that the SUMO-C-L was purified to 92\% (Bandscan 5.0 software, Glyko, Novato, CA, USA). The yield of purified fusion protein SUMO-C-L was approximately $89.14 \mathrm{mg} / \mathrm{L}$ fermentation culture. SUMO-protease recognizing and specifically cleaving the C-terminal Gly-Gly residues of the SUMO part was applied to release $\mathrm{C}-\mathrm{L}$ sequence from the fusion protein. The recombinant $\mathrm{C}-\mathrm{L}$ was cleaved from SUMO-C-L by enzymatic digestion with SUMO-protease at $30^{\circ} \mathrm{C}$ for $3 \mathrm{~h}$ (Figure 3, lane 4). Two protein bands was observed in the lane 4, one was approximately $15 \mathrm{kDa}$, corresponding to the molecular weight of SUMO partner (calculated molecular mass, $15.2 \mathrm{kDa}$ ), and another one was $3 \mathrm{kDa}$, corresponding to the molecular weight of $\mathrm{C}-\mathrm{L}$ (calculated molecular mass, $2.9 \mathrm{kDa}$ ).

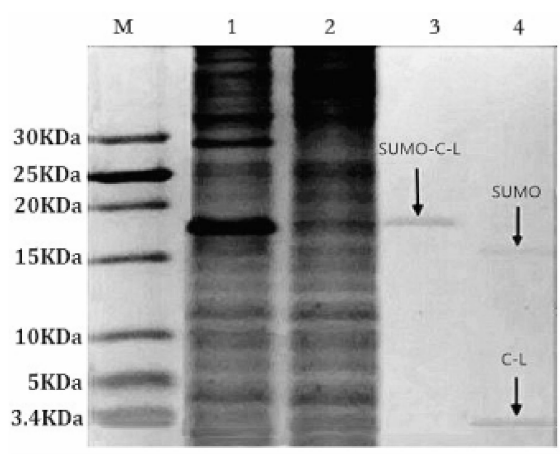

Figure 3. Tricine-SDS-PAGE analysis of purified fusion protein SUMO-C-L. Lane M, the molecular weight of marker; Lane 1, the supernatant of IPTG-induced E. coli BL21 (DE3); Lane 2, the supernatant of non-induced bacterial lysate; Lane 3, the purified fusion protein SUMO-C-L, arrow in the lane indicated the fusion protein SUMO-C-L; Lane 4, the enzymatic reaction solution of fusion protein, arrows in the lane were SUMO and recombinant $\mathrm{C}-\mathrm{L}$. 


\subsection{Purification of Recombinant $C-L$}

The recombinant $\mathrm{C}-\mathrm{L}$ was purified from the cleavage solution with Ni-NTA Sepharose affinity column. Approximately $17.84 \mathrm{mg} / \mathrm{L}$ recombinant C-L was collected. As shown in Figure 4, one single protein band (lane 1) with a molecular mass of about $3 \mathrm{kDa}$ was observed in the dialysis liquid. To be notable, the exact molecular weight of C-L was 2905.37 Da determined by MALDI-TOF (Figure 5), which was basically consistent with calculated value of 2905.70 . After incubation at $37^{\circ} \mathrm{C}$ overnight, growth inhibition of (Staphylococcus aureus) S. aureus ATCC25923 was found around the cylinder to which had been added recombinant $\mathrm{C}-\mathrm{L}$, while no antibacterial activities of SUMO-C-L and sodium phosphate buffer (PBS) were observed (Figure 6).

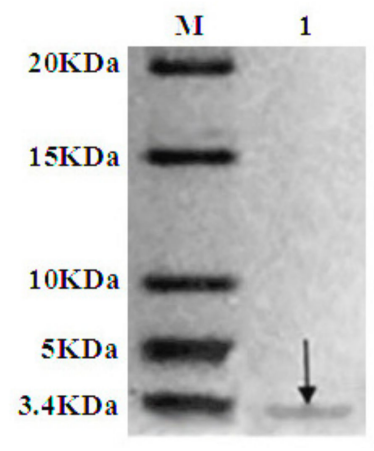

Figure 4. Tricine-SDS-PAGE and antibacterial analysis of purified recombinant C-L. Lane M, the molecular weight of marker; Lane 1, the purified recombinant $\mathrm{C}-\mathrm{L}$, arrow in the lane indicated the recombinant $\mathrm{C}-\mathrm{L}$.

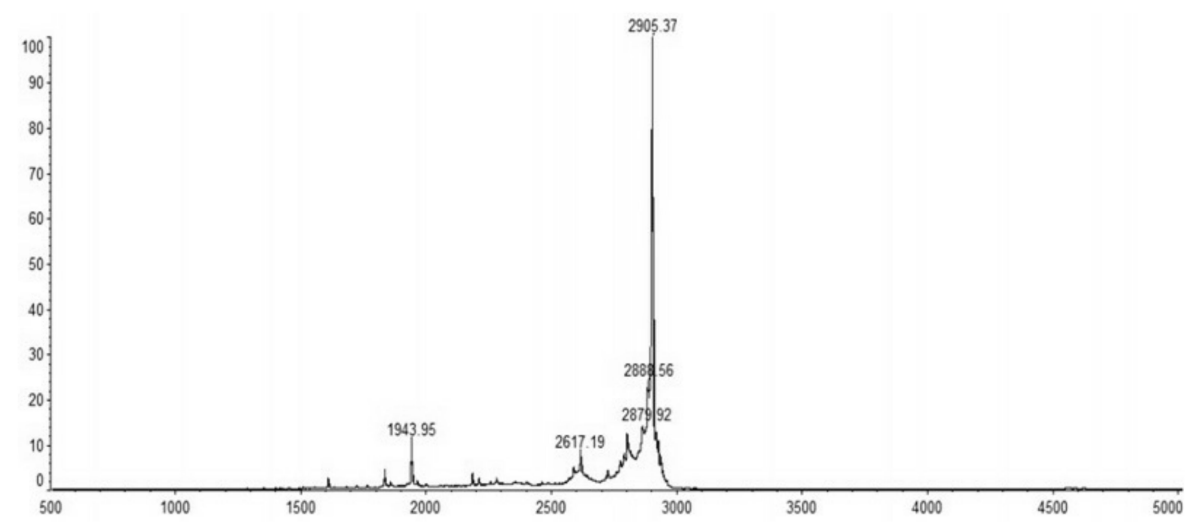

Figure 5. MALDI-TOF/TOF MS mass spectra of purified C-L.

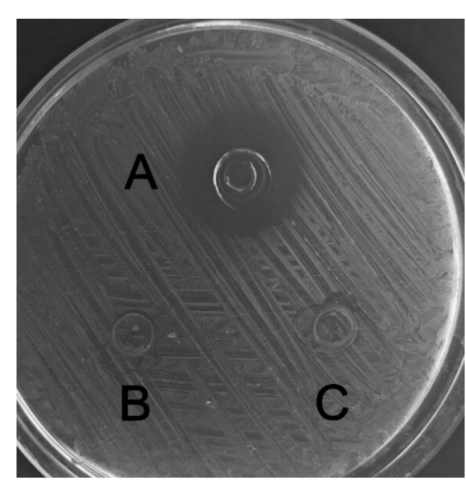

Figure 6. The antimicrobial activity of recombinant $\mathrm{C}-\mathrm{L}$ against $\mathrm{S}$. aureus ATCC25923. A, recombinant $\mathrm{C}-\mathrm{L}$ $(2 \mu \mathrm{g})$; B, fusion SUMO-C-L (10 $\mu \mathrm{g})$; C, the negative control, sodium phosphate buffer (PBS). 


\subsection{Antibacterial and Hemolytic Activity of $C, L$, and $C-L$}

The antibacterial and hemolytic activity (HC50) of $\mathrm{C}, \mathrm{L}$, and $\mathrm{C}-\mathrm{L}$ was determined through microbroth dilution method (Table 1). When compared to parental peptides, the antibacterial activity of $\mathrm{C}-\mathrm{L}$ was greatly improved. It showed that all the three indicator strains were more susceptible to C-L (MICs ranged 2.0-7.2 $\mu \mathrm{g} / \mathrm{mL}$ ) than L (MICs ranged 13.4-85.2 $\mu \mathrm{g} / \mathrm{mL}$ ) and C (MICs ranged $4.2-198 \mu \mathrm{g} / \mathrm{mL})(p<0.01)$. Only very low hemolytic activities of $\mathrm{C}-\mathrm{L}$ to sheep erythrocyte cells were observed in this test $\left(\mathrm{HC}_{50}\right.$ of recombinant and synthesized $\mathrm{C}-\mathrm{L}$ was 221 and $219 \mu \mathrm{g} / \mathrm{mL}$, $\mathrm{HC}_{50}>128 \mu \mathrm{g} / \mathrm{mL}$ was determined as no cytotoxicity) while the $\mathrm{HC}_{50}$ of $\mathrm{C}$ and $\mathrm{L}$ was 169 and $32 \mu \mathrm{g} / \mathrm{mL}$, respectively $(p<0.01)$. Additionally, recombinant $\mathrm{C}-\mathrm{L}$ exhibited similar antibacterial activity to synthesized C-L against E. coli CVCC245, S. aureus ATCC25923, and Listeria monocytogenes CVCC1599 $(p>0.05)$. The $\mathrm{HC}_{50}$ of recombinant $\mathrm{C}-\mathrm{L}$ to sheep erythrocyte cells was agreed with that of synthesized C-L $(p>0.05)$. It is important that antibacterial display little or no hemolytic activity for their safe application in internal medicine.

Table 1. The minimal inhibitory concentrations (MICs) and hemolytic activity $\left(\mathrm{HC}_{50}\right)$ of $\mathrm{C}, \mathrm{L}$, recombinant $\mathrm{C}-\mathrm{L}$, and synthesized $\mathrm{C}-\mathrm{L}$.

\begin{tabular}{|c|c|c|c|c|c|}
\hline \multirow{2}{*}{ Indicated Strains } & \multicolumn{4}{|c|}{ MIC $(\mu \mathrm{g} / \mathrm{mL})$} & \multirow{2}{*}{$p$-Value } \\
\hline & $\mathrm{C}$ & $\mathbf{L}$ & Recombinant C-L & Synthesized C-L & \\
\hline E. coli CVCC 245 & $4.2 \pm 0.35^{c}$ & $85.2 \pm 2.00^{a}$ & $7.2 \pm 0.14^{b}$ & $7.0 \pm 0.21^{b}$ & $<0.01$ \\
\hline S. aureus ATCC 25923 & $198 \pm 10.1^{\mathrm{a}}$ & $58.0 \pm 2.56^{b}$ & $2.2 \pm 0.05^{c}$ & $2.0 \pm 0.02^{c}$ & $<0.01$ \\
\hline L. mono. CVCC 1599 & $64.5 \pm 3.20^{\mathrm{a}}$ & $13.4 \pm 0.50^{b}$ & $2.1 \pm 0.03^{c}$ & $2.2 \pm 0.05^{c}$ & $<0.01$ \\
\hline \multirow{2}{*}{ Indicated cell } & \multicolumn{4}{|c|}{$\mathrm{HC}_{50}(\mu \mathrm{g} / \mathrm{mL})$} & \multirow{2}{*}{$p$-Value } \\
\hline & $\mathrm{C}$ & $\mathbf{L}$ & Recombinant C-L & Synthesized C-L & \\
\hline Sheep erythrocyte cell & $169 \pm 8.20^{b}$ & $32 \pm 1.20^{c}$ & $221 \pm 3.45^{\mathrm{a}}$ & $219 \pm 2.98^{a}$ & $<0.01$ \\
\hline
\end{tabular}

C, cecropin A; L, LL37; MICs, minimal inhibitory concentrations; E. coli, Escherichia coli; S. aureus, Staphylococcus aureus;

L. mono., Listeria monocytogenes; ${ }^{\mathrm{a}, \mathrm{b}, \mathrm{c}}$ Means with different superscripts within the same row differ $(p<0.01)$.

\subsection{Effect of Temperature, $\mathrm{pH}$ and Proteinases on $\mathrm{C}-\mathrm{L}$ Activity}

If an application for humans or livestock is to be found for $\mathrm{C}-\mathrm{L}$, it is important to test for interference factors against its activity. Thermal stability is of great importance because medicine or feed products underwent several heat treatments before reaching the market. Other factors that could interfere with activity would be $\mathrm{pH}$ and enzyme stabilities, since peptides encounter different $\mathrm{pH}$ and enzymes at different digestion stages. Accordingly, the effects of temperature, $\mathrm{pH}$, and proteolytic enzymes on the activity of C-L against $S$. sureus ATCC25923 were determined by inhibition zone assays. The results of heat stability assay confirmed that synthesized $\mathrm{C}-\mathrm{L}$ was heat stable, as the antimicrobial activity of $\mathrm{C}-\mathrm{L}$ was fully retained even after exposing it to $80^{\circ} \mathrm{C}$ for $20 \mathrm{~min}$; however, temperature above $80{ }^{\circ} \mathrm{C}$ reduced the activity of synthesized C-L significantly (Figure 7A). The residual activities of synthesized $\mathrm{C}-\mathrm{L}$ were $>80 \%$ over a broad $\mathrm{pH}$ range, from 4.0 to 11.0 (Figure $7 \mathrm{~B}$ ). Under the challenge of several proteases (proteinase $\mathrm{K}$, trypsin, and pepsin), synthesized $\mathrm{C}-\mathrm{L}$ maintained a portion of functional activity, as shown in Figure 7C. Additionally, compared with synthesized C-L, recombinant $\mathrm{C}-\mathrm{L}$ was shown to retain almost the same stability when given the same heat, $\mathrm{pH}$, and enzymes treatments as above. 
A

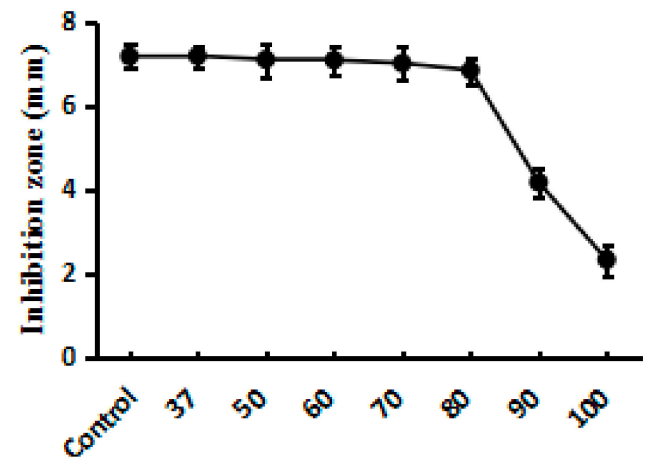

Temperature ( $\left.{ }^{\circ} \mathrm{O}\right)$

B

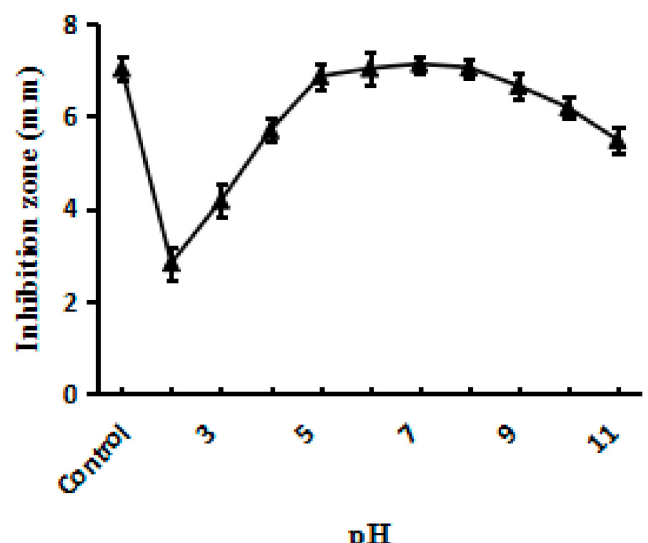

$\mathrm{C}$

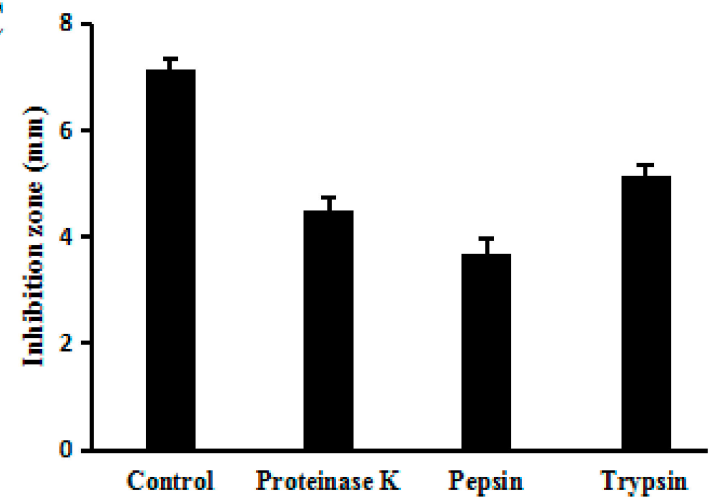

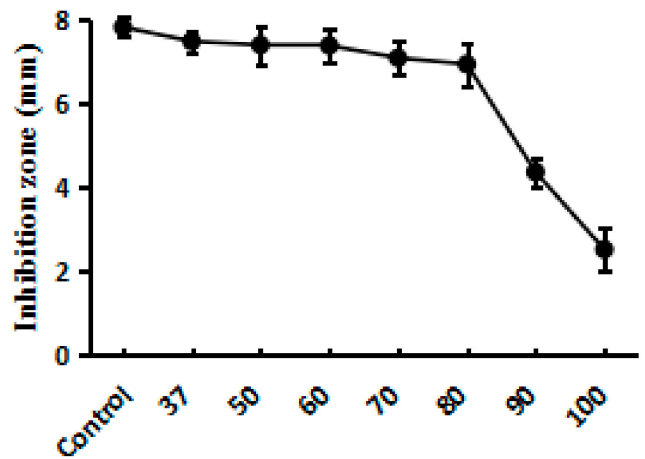

Temperature ( $\left.{ }^{\circ}\right)$

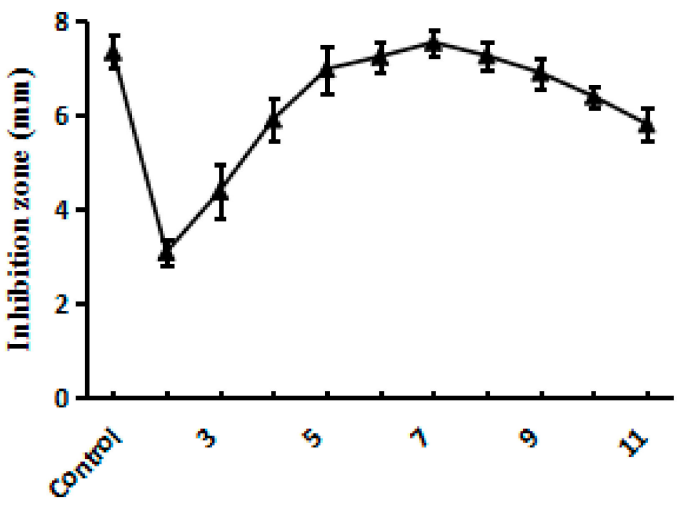

pH

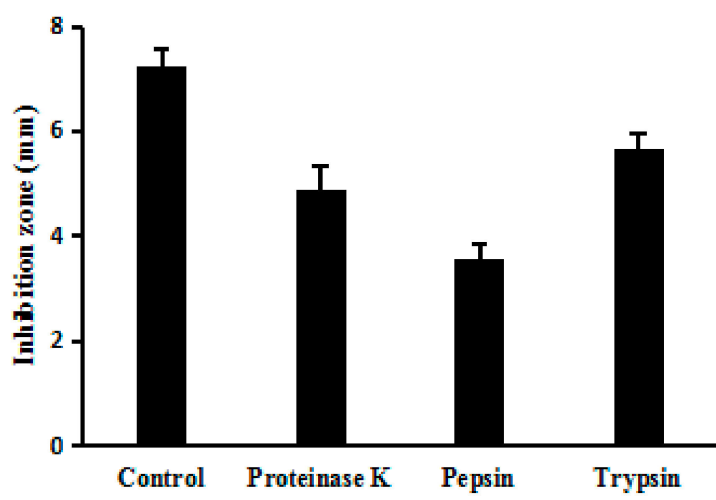

Figure 7. Effects of temperature (A), $\mathrm{pH}(\mathbf{B})$, and proteases (C) on recombinant (left) and synthesized C-L (right). (A) The peptide sample kept at $4{ }^{\circ} \mathrm{C}$ was used as a control. (B) The sample kept in the original culture ( $\mathrm{pH}$ 6.0) was used as a control. (C) The original sample without any enzymatic treatment was used as a control. The graphs were derived from average values for three replicate experiments and error bars show standard deviations. E. coli ATCC25923 was used as the indicator strain.

\section{Discussion}

Hybridizing different AMPs has been a successful practice to improve the properties of native AMPs [14,15]. The hybrid peptide $\mathrm{C}-\mathrm{L}$, combining the core segment of $\mathrm{L}$ with the hydrophobic segment of $C$, was designed, and demonstrated excellent elevated antibacterial activity but minimized cytotoxicity, compared with $\mathrm{C}$ and $\mathrm{L}$ alone. To explore the pharmaceutical potential and medical importance of $\mathrm{C}-\mathrm{L}$, a cost-effective approach for large-scale production is required.

To date, various expression systems have been established for the production of recombinant AMPs $[17,20,23]$. Among them, fusion expression in E. coli system is a common strategy to produce 
AMPs, due to their cytotoxicity to host cells and sensitivity to proteases [24]. The expression vector pET-SUMO, which combines the pET plasmid with SUMO partner together, allows the target gene to be connected with SUMO by "TA" clone to express it effectively and stably under the control of strong T7 promoter [25]. Several AMPs have been efficiently produced using the SUMO fusing system in E. coli $[16,26]$. Thioredoxin, ubiquitin, and GST were also used as fusion partners in E. coli for AMP production [27-29]. The yield of thioredoxin-Mdc [28], ubiquitin-CA-MA2 [29], and GST-LL37 [27] in fermentation solution was 48,32 , and $8 \mathrm{mg} / \mathrm{L}$, respectively. In the present study, the fusion protein SUMO-C-L was successfully expressed in E. coli BL21 (DE3) cells with the yield of $89.14 \mathrm{mg}$ SUMO-C-L per liter fermentation liquid, which was extremely high, indicating the effectiveness of SUMO as a fusion partner.

It is worth noting that the soluble SUMO-C-L was not active, thus, it was necessary to release the recombinant $\mathrm{C}-\mathrm{L}$ by enzymatic cleavage. SUMO protease had the ability to cut off the SUMO tag specifically, consequently allowing the recombinant $\mathrm{C}-\mathrm{L}$ to retain the native $\mathrm{N}$-terminus which was a critical feature for antimicrobial activity [30]. In the present study, the cleaved fusion protein was subjected to tricine-SDS-PAGE, and the size of recombinant $\mathrm{C}-\mathrm{L}$ was consistent with the predicted molecular weight. After purification with Ni-NTA, the recombinant $\mathrm{C}-\mathrm{L}$ was recovered at the yield of $17.34 \mathrm{mg} / \mathrm{L}$, which was higher than $11.2 \mathrm{mg} / \mathrm{L}$ Mdmcec [28], $4.3 \mathrm{mg} / \mathrm{L}$ LL37 [16], and $7.9 \mathrm{mg} / \mathrm{L}$ cecropin B [31]. The purified recombinant C-L showed similar antimicrobial (higher than C and L) and hemolytic (lower than the parental peptides) activity to synthesized $\mathrm{C}-\mathrm{L}$, indicating that the hybrid C-L peptide with excellent antibacterial activity but no cytotoxicity $\left(\mathrm{HC}_{50}>128 \mu \mathrm{g} / \mathrm{mL}\right.$ was determined as no cytotoxicity) was successfully expressed in E. coli BL21 (DE3) and purified with Ni-NTA Sepharose column.

The need to apply $\mathrm{C}-\mathrm{L}$ in human or livestock prompted us to test for interference factors against its activity. The high thermal stability over a temperature range from 37 to $80^{\circ} \mathrm{C}$ revealed the possibility of applying $\mathrm{C}-\mathrm{L}$ in human or farm animals, where the body temperature in which the product must function is close to $40{ }^{\circ} \mathrm{C}$ for both poultry [32] and pigs [33]. More encouragingly, C-L maintained most of the activity in $80^{\circ} \mathrm{C}$, suggesting that it could withstand the high temperature to which the feed is exposed during pelleting.

Knowledge about the peptide function in the $\mathrm{pH}$ range of the gastrointestinal tracts is of crucial importance in the efficient application of an oral agent for animals. The $\mathrm{pH}$ in the stomach, small intestine, and large intestine of piglets 1 week postweaning was measured, and the values ranged from 1.6 to $4.4,3.2$ to 5.8 , and 5.9 to 6.5 , respectively [34]. In the present study, C-L showed significant activity in a wide $\mathrm{pH}$ range from 4.0 to 11.0. This feature enables $\mathrm{C}-\mathrm{L}$ to realize its maximum potential in controlling pathogens, and in modulating the balance of gut flora within the $\mathrm{pH}$ range in the gastrointestinal tracts of recently weaned piglets. However, almost inevitably, a minor part of the $\mathrm{C}-\mathrm{L}$ will lose its antibacterial activity due to gastric digestion, since the $\mathrm{pH}$ value in stomach is lower than 4.0, which could be ameliorated by some processing technologies, such as coating.

It is also important to assess the interference effects of gastric enzymes and pancreatic enzymes on C-L activity, such as pepsin and trypsin, respectively [35]. Additionally, another commonly used enzyme, proteinase $\mathrm{K}$, was detected, which is not secreted in the gastrointestinal tracts of animals, but is useful for general digestion of proteins and removal of endogenous nucleases during the preparation of DNA and RNA. The results from the present study showed that C-L was, to some extent, resistant to proteolytic digestion by these enzymes. However, still nearly half reduction in activity was found when $\mathrm{C}-\mathrm{L}$ was exposed to pepsin. A similar reduction in activity was also seen in Bovicin HC5 (a bacteriocin from Streptococcus bovis HC5) when it was processed by heat and proteinases treatments [36], which indicated the common problem of the susceptibility of antibacterial peptide activity. 


\section{Materials and Methods}

\subsection{Bacterial Strains, Plasmids, and Enzymes}

Three pathogenic microorganisms were obtained from China Veterinary Culture Collection (CVCC, Beijing, China). They were E. coli CVCC245, S. aureus ATCC25923, and Listeria monocytogenes (L. mono.) CVCC1599. The plasmid pET-SUMO (Invitrogen, Carlsbad, CA, USA) was used as cloning vector. E. coli DH $5 \alpha$ and BL21 (DE3) (Novagen, Madison, WI, USA) were cultivated and selected in Luria-Bertani (LB) broth containing $50 \mu \mathrm{g} / \mathrm{mL}$ kanamycin at $37^{\circ} \mathrm{C}$, as the host for gene manipulation and expression of fusion protein, respectively. DNA restriction enzymes, T4 DNA ligase, Taq DNA polymerase, and SUMO protease were purchased from Invitrogen (Carlsbad, CA, USA).

\subsection{Synthesis of Hybrid Peptide}

Hybrid antibacterial peptide $\mathrm{C}-\mathrm{L}$ derived from selected parental peptides ( $\mathrm{C}$ and $\mathrm{L}$ ) was designed using APD2 by fully considering its structure-activity relationship [2]. C-L was synthesized by 9-fluorenylmethoxycarbonyl solid-phase synthesis chemistry and purified by a reverse-phase semi-preparative HPLC (SBS, Shenzhen, China), and then stored at $-80^{\circ} \mathrm{C}$ until use.

\subsection{PCR Amplification and Construction of Expression Vectors}

The C-L gene with appropriate codons for E. coli (http://www.kazusa.or.jp/codon/) was synthesized (Invitrogen, USA) and cloned into pMD18-T (TaKaRa, Otsu, Japan). Plasmid DNA was isolated using a TIAN prep Midi Plasmid Kit (Tiangen, Beijing, China). The gene of C-L was amplified using Taq DNA polymerase (TaKaRa), primer C-L-F (5'-GCCGATGAAATGGAAACTGT-3') and C-L-R (5'-GCGTACTCACTATTAGTTCCTCAG-3'). The PCR condition was $94^{\circ} \mathrm{C}$ for 5 min for hot start, followed by denaturing at $94{ }^{\circ} \mathrm{C}$ for $30 \mathrm{~s}$, annealing at $54{ }^{\circ} \mathrm{C}$ for $30 \mathrm{~s}$, extension at $72{ }^{\circ} \mathrm{C}$ for $45 \mathrm{~s}$, and finally, incubation at $72{ }^{\circ} \mathrm{C}$ for $10 \mathrm{~min}$. The PCR products were separated by $2 \%$ gel electrophoresis, purified with DNA gel extraction kit (Tiangen), and inserted into the linearized pET-SUMO plasmid (Invitrogen) by TA cloning using T4 DNA Ligase (TaKaRa). The ligation mixture was transformed into E. coli Mach1TM-T1R cells, and the recombinant plasmid was verified by PCR amplification and sequencing.

\subsection{Expression of SUMO-C-L Fusion Protein}

The pET-SUMO-C-L plasmid was transformed into competent E. coli BL21 (DE3). The recombinant expression strain was cultivated in LB broth containing $50 \mu \mathrm{g} / \mathrm{mL}$ kanamycin at $37^{\circ} \mathrm{C}$ with shaking $(200 \mathrm{rpm})$ to an optical density $\left(\mathrm{OD}_{600}\right)$ of $0.6 \sim 0.8$. Isopropyl $\beta$-D-1-thiogalactopyranoside (IPTG) $(1.5 \mathrm{mM})$ was then added to induce the expression of the recombinant protein at $37^{\circ} \mathrm{C}$ for $5 \mathrm{~h}$. The cells were harvested by centrifuging at $13,000 \times \mathrm{g}$ for $5 \mathrm{~min}$, and resuspended in lysis buffer $\left(50 \mathrm{mM} \mathrm{K}_{3} \mathrm{PO}_{4}, 400 \mathrm{mM} \mathrm{NaCl}, 100 \mathrm{mM} \mathrm{KCl}, 10 \%\right.$ glycerol, $0.5 \%$ Triton X-100, $10 \mathrm{mM}$ imidazole, pH 7.8), and disrupted by sonication at $200 \mathrm{~W}$ for 80 cycles ( $2 \mathrm{~s}$ working, $8 \mathrm{~s}$ free). After centrifuge at $13,000 \times g$ for $5 \mathrm{~min}$ at $4^{\circ} \mathrm{C}$, the supernatant was collected for tricine-SDS-PAGE analysis.

\subsection{Purification of SUMO-C-L Fusion Protein}

The supernatant was purified with a $10 \mathrm{~mL}$ Ni-NTA Sepharose column (GE Healthcare, Piscataway, NJ, USA). The column was pre-equilibrated with binding buffer (50 $\mathrm{mM} \mathrm{Na}_{3} \mathrm{PO}_{4}, 500 \mathrm{mM}$ $\mathrm{NaCl}, \mathrm{pH}$ 7.4) and the bound protein was eluted by a linear gradient of imidazole from 10 to $400 \mathrm{mM}$ in binding buffer at $2 \mathrm{~mL} / \mathrm{min}$. The eluted fractions were analyzed by tricine-SDS-PAGE, and dialyzed overnight at $4{ }^{\circ} \mathrm{C}$ against $100 \mathrm{mM} \mathrm{NaCl}$. And the fusion protein content was quantified by bicinchoninic acid (BCA) method with three replicates [37]. 


\subsection{Cleavage of SUMO-C-L Fusion Protein and Purification the Recombinant C-L}

The SUMO-C-L protein was cleaved by SUMO protease (Genecopoeia, Rockville, MD, USA) at $30{ }^{\circ} \mathrm{C}$ for $3 \mathrm{~h}$. The recombinant $\mathrm{C}-\mathrm{L}$ protein was purified with Ni-NTA Sepharose column. The enzymatic solution and dialyzed fractions were analyzed by tricine-SDS-PAGE.

\subsection{Antibacterial Studies}

Antibacterial activity of recombinant C-L was assayed by the agar diffusion method with S. aureus ATCC25923 as indicator strain. A dilution of the strain was spread on $\mathrm{MH}$ plates, cylinders were placed on the agar surface, and $100 \mu \mathrm{L}$ of purified recombinant SUMO-C-L $(100 \mu \mathrm{g} / \mathrm{mL})$ and C-L $(20 \mu \mathrm{g} / \mathrm{mL})$ was added to each cylinder. The same volume of PBS was used as negative control. The inhibition zone was measured after incubation overnight at $37^{\circ} \mathrm{C}$. Additionally, the minimal inhibitory concentrations (MICs) of C, L, and C-L were also determined according to the Clinical and Laboratory Standards Institute (CLSI) guidelines using S. aureus ATCC 25923, E. coli CVCC245, and L. mono. CVCC1599 as indicator strains. The indicator strains were cultured at $37^{\circ} \mathrm{C}$ to logarithmic stage and diluted to the concentration of $1 \times 10^{6} \mathrm{cfu} / \mathrm{mL}$ with Mueller-Hinton $(\mathrm{MH})$ broth medium, and $180 \mu \mathrm{L}$ culture was dispensed into per well of 96-well microtiter plate. Peptides were then serially diluted, and dilutions were added into the wells (final volume $200 \mu \mathrm{L}$ ). Each assay was performed in triplicate. After incubation at $37^{\circ} \mathrm{C}$ for $12 \mathrm{~h}$, the plate was assessed by measuring the $\mathrm{OD}_{600}$. The MIC was defined as the lowest concentration (at which there was no change in optical density) required to prevent the growth of bacteria [2].

\subsection{Hemolytic Asssay}

Peptide concentrations that caused 50\% hemolysis of sheep erythrocytes at $540 \mathrm{~nm}$ were measured to evaluate the hemolytic activities [2]. Sheep erythrocytes with $10 \mathrm{mM}$ phosphate buffered saline (PBS) $/ 0.1 \%(v / v)$ Triton X-100 (Sigma, San Francisco, CA, USA) added were used as negative/positive control. Assays were performed in triplicate.

\subsection{Assessment of Stability}

The stability of the purified recombinant $\mathrm{C}-\mathrm{L}$ and synthesized $\mathrm{C}-\mathrm{L}$ at different $\mathrm{pH}$ values (2.0-11.0) and different temperatures $\left(37,50,60,70,80,90\right.$, and $100{ }^{\circ} \mathrm{C}$ for $20 \mathrm{~min}$ ) was evaluated. The susceptibility of C-L to pepsin, trypsin, and proteinase $\mathrm{K}(10 \mu \mathrm{g} / \mathrm{mL}$ in PBS) was measured by adding it to a solution of the peptide in PBS $(1 \mu \mathrm{M})$ [38]. Stability of recombinant $\mathrm{C}-\mathrm{L}$ and synthesized $\mathrm{C}-\mathrm{L}$ was assessed by the agar diffusion method as described above and the inhibition zones were recorded. S. aureus ATCC25923 was used as the indicator strain and the inhibition zones were recorded.

\section{Conclusions}

In summary, an effective approach was created for overproducing a novel hybrid peptide C-L in E. coli. SUMO fusion technology was successfully used to eliminate the toxicity and proteolytic degradation of $\mathrm{C}-\mathrm{L}$ peptide. High recovery yield of recombinant $\mathrm{C}-\mathrm{L}$ with potential antimicrobial activity was obtained after efficient cleavage of SUMO protease and simple purification. The purified C-L displayed identical antibacterial and hemolytic activities to synthesized C-L, which is significantly superior to the parental peptides. Antimicrobial activity was displayed at the temperature and $\mathrm{pH}$ ranges commonly found in the farm animal body. In addition, $\mathrm{C}-\mathrm{L}$ was, to some extent, resistant to proteolytic digestion of several common enzymes. These findings indicate that the $E$. coli expression system and SUMO fusion strategy have great potential for high-level expression of various kinds of valuable peptides and proteins. Furthermore, as a novel hybrid peptide with excellent properties, $\mathrm{C}-\mathrm{L}$ is expected to serve as a useful antimicrobial or even therapeutic agent for animals or possibly humans. 
Author Contributions: X.W. and R.W. performed the experiments and wrote the paper; L.Z. conceived and designed experiments; B.A. analyzed the data; R.Z. and D.S. guided the experiments. All authors helped to prepare the paper and approved the final version.

Funding: This research was funded by the National Natural Science Foundation of China (No. 31272476 and 31572442) and the Specialized Research Fund for the Doctoral Program of Higher Education of China (No. 20110008110002).

Acknowledgments: This research was funded by the National Natural Science Foundation of China (No. 31272476 and 31572442) and the Specialized Research Fund for the Doctoral Program of Higher Education of China (No. 20110008110002).

Conflicts of Interest: The authors declare no conflict of interest.

\section{References}

1. Santos, N.A.; Fernandes, R.S.; Sgardioli, B.F.; Ramos, M.A.S.; Piccoli, J.P.; Camargo, I.L.B.C.; Bauab, T.M.; Cilli, E.M. Antibacterial activity of the non-cytotoxic peptide (p-BthTX-I)(2) and Its serum degradation product against multidrug-resistant bacteria. Molecules 2017, 22, 1898. [CrossRef] [PubMed]

2. Wei, X.B.; Wu, R.J.; Si, D.Y.; Liao, X.D.; Zhang, L.L.; Zhang, R.J. Novel hybrid peptide cecropin A (1-8)-LL37(17-30) with potential antibacterial activity. Int. J. Mol. Sci. 2016, 17, 983. [CrossRef] [PubMed]

3. Lai, Y.P.; Gallo, R.L. AMPed up immunity: How antimicrobial peptides have multiple roles in immune defense. Trends Immunol. 2008, 30, 131-141. [CrossRef] [PubMed]

4. Deptula, M.; Wardowska, A.; Dzierzynska, M.; Rodziewicz-Motowidlo, S.; Pikula, M. Antibacterial peptides in dermatology-strategies for evaluation of allergic potential. Molecules 2018, 23, 414. [CrossRef] [PubMed]

5. Pantic, J.M.; Jovanovic, I.P.; Radosavljevic, G.D.; Arsenijevic, N.N.; Conlon, J.M.; Lukic, M.L. The potential of frog skin-derived peptides for development into therapeutically-valuable immunomodulatory agents. Molecules 2017, 22, 2071. [CrossRef] [PubMed]

6. Yeaman, M.R.; Yount, N.Y. Mechanisms of antimicrobial peptide action and resistance. Pharmacol. Rev. 2003, 55, 27-55. [CrossRef] [PubMed]

7. Reddy, K.V.R.; Yedery, R.D.; Aranha, C. Antimicrobial peptides: Premises and promises. Int. J. Antimicrob. Agents. 2004, 24, 536-547. [CrossRef] [PubMed]

8. Brogden, K.A. Antimicrobial peptides: Pore formers or metabolic inhibitors in bacteria? Nat. Rev. Microbiol. 2005, 3, 238-250. [CrossRef] [PubMed]

9. Wang, G.S.; Mishra, B.; Epand, R.F.; Epand, R.M. High-quality 3D structures shine light on antibacterial, anti-biofilm and antiviral activities of human cathelicidin LL-37 and its fragments. Biochim. Biophys. Acta-Biomembr. 2014, 1838, 2160-2172. [CrossRef] [PubMed]

10. Ramos, R.; Silva, J.P.; Rodrigues, A.C.; Costa, R.; Guardao, L.; Schmitt, F.; Soares, R.; Vilanova, M.; Domingues, L.; Gama, M. Wound healing activity of the human antimicrobial peptide LL37. Peptides 2011, 32, 1469-1476. [CrossRef] [PubMed]

11. Thennarasu, S.; Tan, A.M.; Penumatchu, R.; Shelburne, C.E.; Heyl, D.L.; Ramamoorthy, A. Antimicrobial and membrane disrupting activities of a peptide derived from the human cathelicidin antimicrobial peptide LL37. Biophys. J. 2010, 98, 248-257. [CrossRef] [PubMed]

12. Bacalum, M.; Radu, M. Cationic antimicrobial peptides cytotoxicity on mammalian cells: An analysis using therapeutic index integrative concept. Int. J. Pept. Res. Ther. 2015, 21, 47-55. [CrossRef]

13. Giacometti, A.; Cirioni, O.; Kamysz, W.; Amato, G.; Silvestri, C.; Del Prete, M.S.; Lukasiak, J.; Scalise, G. Comparative activities of cecropin A, melittin, and cecropin A-melittin peptide CA(1-7)M(2-9)NH2 against multidrug-resistant nosocomial isolates of Acinetobacter baumannii. Peptides 2003, 24, 1315-1318. [CrossRef] [PubMed]

14. Tan, T.T.; Wu, D.; Li, W.Z.; Zheng, X.; Li, W.F.; Shan, A.S. High specific selectivity and membrane-active mechanism of synthetic cationic hybrid antimicrobial peptides based on the peptide FV7. Int. J. Mol. Sci. 2017, 18, 339. [CrossRef] [PubMed]

15. Saugar, J.M.; Rodriguez-Hernandez, M.J.; de la Torre, B.G.; Pachon-Ibanez, M.E.; Fernandez-Reyes, M.; Andreu, D.; Pachon, J.; Rivas, L. Activity of cecropin A-melittin hybrid peptides against colistin-resistant clinical strains of Acinetobacter baumannii: Molecular basis for the differential mechanisms of action. Antimicrob. Agents Chemother. 2006, 50, 1251-1256. [CrossRef] [PubMed] 
16. Bommarius, B.; Jenssen, H.; Elliott, M.; Kindrachuk, J.; Pasupuleti, M.; Gieren, H. Cost-effective expression and purification of antimicrobial and host defense peptides in Escherichia coli. Peptides 2010, 31, 1957-1965. [CrossRef] [PubMed]

17. Wu, G.Q.; Li, L.X.; Ding, J.X.; Wen, L.Z.; Shen, Z.L. High-level expression and novel purification strategy of recombinant thanatin analog in Escherichia coli. Curr. Microbiol. 2008, 57, 95-101. [CrossRef] [PubMed]

18. Demonte, D.; Dundas, C.M.; Park, S. Expression and purification of soluble monomeric streptavidin in Escherichia coli. Appl. Microbiol. Biotechnol. 2014, 986, 285-295. [CrossRef] [PubMed]

19. Tomala, M.; Lavrentieva, A.; Moretti, P.; Rinas, U.; Kasper, C.; Stahl, F. Preparation of bioactive soluble human leukemia inhibitory factor from recombinant Escherichia coli using thioredoxin as fusion partner. Protein Expr. Purif. 2010, 73, 51-57. [CrossRef] [PubMed]

20. Luan, C.; Zhang, H.W.; Song, D.G.; Xie, Y.G.; Feng, J.; Wang, Y.Z. Expressing antimicrobial peptide cathelicidin-BF in Bacillus subtilis using SUMO technology. Appl. Microbiol. Biotechnol. 2014, 98, 3651-3658. [CrossRef] [PubMed]

21. Wang, L.N.; Quan, C.S.; Liu, B.Q.; Xu, Y.B.; Zhao, P.C.; Xiong, W.; Fan, S.D. Green fluorescent protein (GFP)-based overexpression screening and characterization of AgrC, a receptor protein of quorum sensing in Staphylococcus aureus. Int. J. Mol. Sci. 2013, 14, 18470-18487. [CrossRef] [PubMed]

22. Lee, J.H.; Kim, J.H.; Hwang, S.W.; Lee, W.J.; Yoon, H.K.; Lee, H.S. High-level expression of antimicrobial peptide mediated by a fusion partner reinforcing formation of inclusion bodies. Biochem. Biophys. Res. Commun. 2000, 277, 575-580. [CrossRef] [PubMed]

23. Iglesias-Figueroa, B.; Valdiviezo-Godina, N.; Siqueiros-Cendon, T.; Sinagawa-Garcia, S.; Arevalo-Gallegos, S.; Rascon-Cruz, Q. High-level expression of recombinant bovine lactoferrin in Pichia pastoris with antimicrobial activity. Int. J. Mol. Sci. 2016, 17, 902. [CrossRef] [PubMed]

24. Chen, Y.Q.; Zhang, S.Q.; Li, B.C.; Qiu, W.; Jiao, B.; Zhang, J. Expression of a cytotoxic cationic antibacterial peptide in Escherichia coli using two fusion partners. Protein Expr. Purif. 2008, 57, 303-311. [CrossRef] [PubMed]

25. Butt, T.R.; Edavettal, S.C.; Hall, J.P.; Mattern, M.R. SUMO fusion technology for difficult-to-express proteins. Protein Expr. Purif. 2005, 43, 1-9. [CrossRef] [PubMed]

26. Li, B.C.; Zhang, S.Q.; Dan, W.B.; Chen, Y.Q.; Cao, P. Expression in Escherichia coli and purification of bioactive antibacterial peptide ABP-CM4 from the Chinese silk worm, Bombyx mori. Biotechnol. Lett. 2007, 29, 1031-1036. [CrossRef] [PubMed]

27. Moon, J.Y.; Henzler-Wildman, K.A.; Ramamoorthy, A. Expression and purification of a recombinant LL-37 from Escherichia coli. Biochim. Biophys. Acta-Biomembr. 2006, 1758, 1351-1358. [CrossRef] [PubMed]

28. Xu, X.; Jin, F.; Yu, X.; Ji, S.; Wang, J.; Cheng, H. Expression and purification of a recombinant antibacterial peptide, cecropin, from Escherichia coli. Protein Expr. Purif. 2007, 53, 293-301. [CrossRef] [PubMed]

29. Xu, X.; Jin, F.; Yu, X.; Ren, S.; Hu, J.; Zhang, W. High-level expression of the recombinant hybrid peptide cecropinA(1-8)-magainin2(1-12) with an ubiquitin fusion partner in Escherichia coli. Protein Expr. Purif. 2007, 55, 175-182. [CrossRef] [PubMed]

30. Wu, M.H.; Hancock, R. Interaction of the cyclic antimicrobial cationic peptide bactenecin with the outer and cytoplasmic membrane. J. Biol. Chem. 1998, 274, 28-35. [CrossRef]

31. Yu, F.; Wang, J.; Zhang, P.; Hong, Y.; Liu, W. Fusion expression of cecropin B-like antibacterial peptide in Escherichia coli and preparation of its antiserum. Biotechnol. Lett. 2010, 32, 669-673. [CrossRef] [PubMed]

32. Lacey, B.; Hamrita, TK.; Lacy, M.P.; Van Wicklen, G.L.; Czarick, M. Monitoring deep body temperature responses of broilers using biotelemetry. J. Appl. Poult. Res. 2000, 9, 6-12. [CrossRef]

33. Warriss, P.D.; Pope, S.J.; Brown, S.N.; Wilkins, L.J.; Knowles, T.G. Estimating the body temperature of groups of pigs by thermal imaging. Vet. Rec. 2006, 158, 331-334. [CrossRef] [PubMed]

34. Snoeck, V.; Cox, E.; Verdonck, F.; Joensuu, J.J.; Goddeeris, B.M. Influence of porcine intestinal pH and gastric digestion on antigenicity of F4 fimbriae for oral immunisation. Vet. Microbiol. 2004, 98, 45-53. [CrossRef] [PubMed]

35. Low, A.G. The activity of pepsin, chymotrypsin and trypsin during $24 \mathrm{~h}$ periods in the small intestine of growing pigs. Br. J. Nutr. 1982, 48, 147-159. [CrossRef] [PubMed]

36. Mantovani, H.C.; Hu, H.J.; Worobo, R.W.; Russell, J.B. Bovicin HC5, a bacteriocin from Streptococcus bovis HC5. Microbiology 2002, 148, 3347-3352. [CrossRef] [PubMed] 
37. Osnes, T.; Sandstad, O.; Skar, V.; Osnes, M.; Kierulf, P. Total protein in common duct bile measured by acetonitrile precipitation and a micro bicinchoninic acid (BCA) method. Scand. J. Clin. Lab. Investig. 1993, 53, 757-763. [CrossRef]

38. Papo, N.; Shai, Y. A molecular mechanism for lipopolysaccharide protection of gram-negative bacteria from antimicrobial peptides. J. Biol. Chem. 2005, 280, 10378-10387. [CrossRef] [PubMed]

Sample Availability: Samples of the compounds antibacterial peptides are available from the authors.

(C) 2018 by the authors. Licensee MDPI, Basel, Switzerland. This article is an open access article distributed under the terms and conditions of the Creative Commons Attribution (CC BY) license (http:/ / creativecommons.org/licenses/by/4.0/). 